\title{
8 Physical Impairment and the Spatial Dimensions of Everyday Life in Rural Households in Pre-industrial Iceland
}

\author{
Ólafur Rastrick
}

\section{Introduction}

A number of studies exploring disability and housing address the question of how design and layout of dwelling and home environment affects the quality of life of individuals who are physically impaired (Imrie 2004). Mostly confined to contemporary society and modern spaces, these studies adhere for instance to questions of access, segregation, activity, and participation in and out of the home of people whose mobility is restricted (Imrie and Edwards 2007, Titchkosky 2011, Wiesel and van Holstein 2020). Transposing such concerns onto traditional rural households in Iceland, the chapter seeks to illustrate and analyse the "social space of disability" (Gleeson 1999, 2001) within the turf-house-based community, exploring the predicaments of people with physical impairments as regards the domestic space of the turf-house and relating it to broader historical-geographical character of 19 th and early 20 th century Iceland.

The discussion rests on the premises that the pre-industrial Icelandic economy was almost entirely household-based till the late 1800s and in some rural areas well into the 20th century, with the rural household as the unit of production (Gunnarsson 1987, Magnússon 1985). A large part of everyday existence of the community in general, including work and education, thus, took place within the confined space of the bar (turf-house cluster). As disability writer Vic Finkelstein (1981) and others have noted from cases elsewhere, the predicaments of people with physical impairments in such pre-industrial societies differed greatly in this context from what emerged in the urbanised modernity that followed the Industrial Revolution. This line of argument has led disability theorist Tom Shakespeare (2018) to conclude that "from the disability perspective, the way of life in pre-industrial, pre-capitalist times might have been more inclusive, for those that survived their illness or injury" (Shakespeare, p. 27). On this note the chapter seeks to explore the relationship between disability and space within the turf-house setting, illustrating ways in which architecture and the social space of the turf-house interacted with everyday life of physically impaired individuals.

DOI: $10.4324 / 9781003180180-9$ 
Special attention will be given to the cases of two individuals with physical impairment: 1) the pauper Kristján Benediktsson and 2) the farmer Árni Jakobsson. Kristján's legs and fingers had been amputated after severe frostbite in his early 20 s and he remained in a state of pauperism throughout his life. Árni on the other hand took up farming along with his wife in the remote highlands of northern Iceland in early 20th century, after contracting polio at the age of 23 which left him paralysed from the waist down. The latter's unique memoirs published posthumously (Jakobsson 1963) offer vivid insight into the relationship between an impaired body and the domestic space of the turf-house. The chapter argues that in important ways the social structure of the turf-house-based community, and, especially, the spatial design and the vernacular architecture of the turf-house, created a very different dynamic between space and "different" bodies than the modernist spaces of the industrialised urban spaces did later on. It is indeed suggested that the social and domestic space of the turf-house-based community did in a sense have a less disabling effect on individuals with physical impairments than the spatial design of the society that supplanted it.

\section{The centrality of the rural household in pre-industrial Iceland}

The structure of Icelandic society, both socially and economically, was more or less untouched by the effects of the industrial revolution until the 20th century. Until the late 1800 s almost the entire Icelandic population (of 70,000 in 1875) relied on subsistence farming for survival in the harsh climate of the North Atlantic, living in sparsely distributed hamlets or cottages, mostly in the coastal regions but also inland in some areas. Due to legal restrictions, towns did not emerge until the late 19th century with the population of the largest, Reykjavik, only reaching 6.000 at the turn of the 20th century (Karlsson 2000). One of the main legal obstacles to urban development lies in the system of vistarband which required everybody that did not own or lease a farmstead to become a labourer/domestic servant at a farm (Vilhelmsson 2017). Those who could not provide for themselves for some reason, such as impairment, often ended up as paupers (niðursetningur), assigned for payment to a household by the local government. Poorhouses/hospitals did exist in the country till mid-19th century but were then abandoned. However, such institutions would at any time only have housed between 16-20 individuals in total. The historian Gísli Ágúst Gunnlaugsson (1983) estimated for the 18 th century that paupers were on average around $10 \%$ of the population, or between 4-5.000. Modern medical institutions designed to support individuals with impairments did not exist to any extent until the turn of the 20th century with the founding of establishments, such as the leprosarium at Laugarnes in 1898 and the mental health care hospital at Kleppur in 1907 (Guðjónsson 2013a, Halldórsdóttir 2020). This meant that people 
with mental and physical impairments who had access to stable residence were to a lesser extent spatially segregated from others and lived nonsegregated within households, even though multiple exceptions are known, where, especially, people with psychiatric issues were locked up in shacks and outhouses (Guðjónsson 2013a, 2013b).

A typical rural household in the 19th century would consist of a farmer and his wife, children, sometimes aged parents, domestic servants, and often paupers. Most households were economically dependent on domestic production, relying on work carried out within the domestic space, especially, processing wool (Karlsson 2000, Gunnlaugsson 1988). This does not mean that all work was performed in the cottages - a significant part of the labour, such as tending animals and harvesting (hay) was usually undertaken in the proximity of the farmhouse - while other economically significant activity required more mobility. Such activities included looking after or heading livestock, overseeing shielings (sel), collecting Iceland moss (fjallagrös), and travelling seasonally to distant parts of the country for fishing (Jónasson 2010).

The economic position of people with physical impairments within the rural household is in many ways comparable to their place in other preindustrial societies. Addressing the transformation to the work-related predicament of people with physical impairments prior to the Industrial Revolution in England, Vic Finkelstein, already in 1981, drew attention to the role of "cripples" in the pre-industrial household-based economy.

Apart from performing domestic duties for their families, such as cooking, making clothes, and looking after the young children, when possible, cripples [sic.] unable to perform agricultural work could have supplemented the family income by spinning and weaving. Small and portable, the early machines could have been easily adapted to suit individual physiques. The work was carried out in their homes and cripples had no need to seek employment beyond the family (Finkelstein 1981, no pagination).

This was to change, Finkelstein (1981) asserts, with the emergence of capitalism and industrial urbanism. In 19th century England traditional cottage industry was no longer competitive and the most vulnerable, people with impairments were forced to turn to begging and church protection in poorhouses. The market favoured the industrialised factories which produced woven material more efficiently (Finkelstein, 1981, Gleeson 1999, Oliver 1990, Oliver and Barnes 2012). Conversely, in agrarian societies, as Shakespeare (2018) illustrates, "whether in medieval Europe or in rural parts of Africa and Asia today" (p. 28-29) - or indeed 19th and early 20th century rural Iceland - "disabled people experienced a similar level of poverty or hardship as everyone else (p. 29)." In a society where the household is the unit of production everyone belonging to that household could potentially 
contribute for its benefit. Drawing on his research in Africa, Shakespeare (2018) concludes:

If everyone is working at subsistence levels, and households support all its members, then disabled people may not be as disadvantaged as we might imagine. Really determined individuals can sometimes manage to do very well (p. 28).

The central section of 19th century turf-house was the baðstofa, the communal room of each household which functioned simultaneously as bedroom, dining room, and workspace for the cottage industry and in most cases the space for receiving visitors. Indeed, much of the everyday was confined to the space of baðstofa, especially, during winter from October until April. As the historian Gunnar Karlsson (2000) notes, "it was customary for the whole household to live practically all their indoor life in the baðstofa, often with two sharing each bed" (p. 250). This gave little leeway for privacy in the sense that is associated with the modern notion of home as sanctuary (Hálfdanarson 2008). The baðstofa functioned also as the main space for religious practice, schooling, and leisure, most notably in the form of the evening veillée ( $k v o ̈ l d v a k a)$, consisting of both religious and secular activities. Though some attended church regularly or occasionally, daily religious observation was a central part of the kvöldvaka where a designated individual would read out loud for the benefit of the entire household. In addition to religious texts, the sagas or other vernacular prose or poetry would be read aloud. The kvöldvaka might also include the singing of psalms and performance of various kinds, such as storytelling and reciting or chanting of the local form of ballads, rímur (Gíslason 1977, Jónasson 2010). Primary schools were virtually unheard of in rural areas before the 20th century so both religious education and instruction in reading (and eventually writing and arithmetic) took place at home and was the responsibility of the household under the supervision of the local priest (Guttormsson 2008). The teaching would have usually taken place in the baðstofa.

Like in matters of economic production, all members of the household, including those with various forms of impairment, would have taken part or at least been present during cultural consumption in the turf-house. Even though examples of segregation of individuals with mental disorders exist (Guðjónsson 2013a), most individuals with impairments would have shared the space of the baðstofa with other people of the household. This would also be the case with visitors, including those who lived outside the vistarband system that required everyone that did not own or lease a property to be employed on a farm.

Vagrancy was commonly seen as social menace by the ruling elite and many independent farmers. However, as ethnologist Jón Jónsson (2018) has demonstrated, vagrancy was interwoven in the socio-economic structure of the peasant society and vagrants often provided services that were 
sought after. To survive, these individuals were to some extent receivers of alms, travelling between farmsteads seeking food and lodgings, but also performing various services, such as undertaking specific chores or offering entertainment in form of stories, news, gossip, or other types of performance during the kvöldvaka. As a rule, the vagrants joined the rest of the household in the baðstofa during their stay, even though they sometimes outstayed their welcome at the farm.

A number of the vagrants Jónsson (2018) explores can be said to have had some form of physical or mental impairment. Thus, even though the social space of many individuals with physical or sensory impairments may have been confined to the constellation of the farmhouse (bær) others travelled (for longer or shorter periods) from one household to the next, seeking alms or rendering services of some sort.

\section{Disability, domestic space, and the vernacular architecture of the turf-house}

The turf-houses enjoy a paradoxical reputation in Icelandic cultural history. Through a process of rapid modernisation, turf-houses went from being the prevailing form of residential housing in the early 1900s, especially, in rural areas, to having virtually disappeared by mid-century (Jónsson and Magnússon 1997). The emerging medical profession at the turn of the century proclaimed these buildings unsanitary dwellings and the proponents of cultural modernisation, echoing foreign perceptions, deemed them shamefully primitive, not appropriate as the residences for a proud civilised nation (Hafsteinsson 2019, Hafsteinsson and Jóhannesdóttir 2015, Rastrick 2013). Conversely, the turf-houses also had a place in the romanticised vocabulary of the patriots of the nationalist movement of the late 19th and early 20th century who saw them as embodying the symbiotic relation between nation and land (Rastrick 2012). Furthermore, in recent years, the few remaining (showcase) turf-buildings have gained renewed interest as endangered cultural heritage and as a more sustainable mode of housing in times of climate awareness (Sigurðardóttir 2020, Kreps 2019). Whether turf-houses are a testimony of the poverty stricken past (Magnússon 2019) or a clever synthesis of centuries of human habitation in the harsh climate of the North and a guiding light for a sustainable future (Lárusson 2014), is a matter of debate (Hafsteinsson 2010).

Without doubt the turf-houses were often unpleasant dwellings. While ample descriptions of clean and warm turf-houses exist, others portray them as miserably dark, filthy, and damp (Emilsson 1976). "Take care when you get inside," the French scientist Paul Gaimard wrote in his diary reciting the advice of a local official upon entering the cottage Krossanesbær in Iceland's North, "you might inadvertently sit on a leper." After describing the harrowing circumstances of the young man found in the turfhouse, Gaimard concludes: "Our visit to this croft was testimony of the great human misery that is apparent in Iceland" (cited in Snævarr 2019). 
For persons with diseases or otherwise impaired, the quality of housing affected the quality of life, even more so than it did for others. However, other aspects of everyday life in the turf-house give pause for thought about the spatial predicaments the vernacular architecture of the turf-house fostered for people with physical impairments in comparison with the type of dwellings that replaced them.

The modern idea of the home is often seen in idealistic terms as a safe haven or retreat from the toils of everyday life, a place of security, privacy, and independence. This perception has been challenged from a variety of perspectives, for instance noting that the home is for some a place of violence (Warrington 2001) and loneliness and social disengagement (Macdonald et al. 2018). Writing on the domestic experience of people with impairment in modern society, geographer, and disability scholar Rob Imrie $(2003,2004)$ highlights the role of spatial design of homes in having disabling effects on persons with physical impairment. This, Imrie (2004) maintains, is in part "because design conceptions, in relation to floor plans and allocation of functions to specific spaces, do not conceive of impairment, disease and illness as part of domestic habitation or being" (p. 746). Thus, it can be said that design and layout of the home environment directly affects the quality of life of individuals that are physically impaired. Imrie (2004), does, however, not endorse the view he associates with the social model of disability which he claims, "tends to conceive of individuals as 'victims' of circumstances beyond their control, in which they are oppressed by social and environmental factors" (p. 756). Conversely, he argues that people with impairments are "not passive victims of insensitive design" (Imrie 2004, p. 756) but can and do, as his study illustrates, embody "capacity to generate useable spaces out of the social and physical impediments that are placed in their way" (Imrie 2044, p. 756).

Returning on that note to the turf-house, it has been described as an organic structure in a perpetual state of construction. For adequate maintenance of the cluster of houses that constitute a bær the farmer/occupant would as a rule have to undertake repairs on the structure every year rebuilding or renewing a wall, roof, or whole sections of the building cluster. Working with organic materials found in proximity of the farm, such as stones and turf (and timber, especially, where driftwood was readily accessible), the architecture of the buildings was subject to building materials at hand (Sigurðardóttir 2008, 2012, Stefánsson 2013, Lárusson 2014, van Hoof and van Dijken 2008). Furthermore, the structure of the buildings would in some instances vary from time to time, depending upon economic resources and needs of the households. For instance, during dire times the buildings tended to become more compact. While, as with other types of vernacular architecture, the building of a turf-house was based on knowledge and experience, no bær was identical. Different from the standardised modernist building (Imrie 2000) the ongoing rebuilding of the turf-house opened for continual architectural adaption to suit the needs of the inhabitants within the confines of resources and know how. 
One of the outcomes of drawing attention to the interlinkage between design and wellbeing is the introduction of the notion of universal design (UD). The adoption of this approach in policy and design can be seen as a consequence of the paradigmatic shift in focus associated with the social model of disability, referred to above. Instead of seeing the individual as disabled due to medical defects or dysfunction, society and its structure are identified as having disabling effects on the individual that diminishes accessibility, the quality of life and human rights of individuals with impairments. Proponents of universal design have sought to counter the tendency of, for example, modernist architecture to design for the normalised body and thus disregarding human diversity. Instead, proponents of UD seek ways for design "to be usable by all people, to the greatest extent possible, without the need for adaptation or specialized design" [CRPD 2006: Art. 2 (5)]. In terms of architectural design, the call for universal design targets consequences of modern production techniques that favour standardisation of furniture, height of cabinets, etc. This is also directed at things like stairs, that disregard that in many cases reduce the mobility of people with physical impairments.

Universal design targets certain effects of modernity, such as architectural design that has disabling effects on the individual with impairments, reducing mobility, hindering execution of various tasks, and curbing social participation, among others. The past offers of course ample examples of such disabling effects of the environment, such as the lack of support equipment. However, pre-industrial architecture was much less prone to standardisation than modern housing. This applies, especially, to premodern vernacular architecture where standardisation was by definition non-existent. The notion of universal design can hardly be seen as applicable to analysing pre-modern contexts. However, it draws attention to disabling character embedded in modern architecture and urban design which is also reflected in elements of industrial and post-industrial society, such as spatial division of home and workplace. Thus, the notion is useful in the historical context as a critical stance towards the idea of homogenous progress and opens up space to compare predicaments of people with impairments in pre-modern societies, such as the Icelandic turf-housebased community, to the hindrances met by such individuals in urbanised modernity. To be able to make this comparison, or to be able to assess how changing socio-spatial organisation interacted with the lived experience of persons with physical impairment (Gleeson 1999), it is necessary to look more closely at the nature of the turf-house.

\section{Physical impairment and everyday life in the turf-house}

The following discussion refers to persons with physical impairments who lived and worked in turf-houses. The objective is to give insight into how their everyday lives were mediated by the physical and social space of the 
vernacular architecture and its socio-cultural context. It should be stressed that there are many types of physical impairments that affected people in different ways and that the predicaments of individuals in the turf-house community were diverse. The cases referred to should be seen as such and may or may not be representative of a larger population. The pretext to the discussion rests on the above comparison between the socio-cultural context of traditional rural Iceland and the modern urbanised world, the latter being premised to a much larger extent on daily mobility of individuals and standardisation of the built environment. Speculating on notions of activity as "execution of a task or action by an individual" and participation as "involvement in life situations" (WHO 2001, p. 10, Chang and Coster 2014) it is suggested that both social structure and vernacular architecture of pre-modern Iceland facilitated activity and participation that was met with hindrance at the onset of urban modernity.

Commenting on the scarcity references to impairment in historical documents, Gleeson (1999, p. 97-98) notes that bodily impairment was "doubtless an accepted, prosaic element of peasant life" and thus went generally unnoticed. What he refers to as the "ubiquity of impairment" can thus explain its "relative invisibility" in historical records (Le Goff 1988, Metzler 2013). Reflecting that perspective on to Icelandic peasant society there seems to be no reason to suspect that this was not the case there. Both in public documentation, such as census material, and private sources, bodily impairment was in all probability underrepresented because it was relatively common. However, some relatively reliable first-hand descriptions exit, reflecting the predicaments of the bodily impaired in preindustrial rural Iceland.

\section{The case of Kristján "The Legless"}

One common form of injury that caused impairment in Icelandic peasant society of previous centuries was frostbite. Harsh and unstable climate during winter left many seafarers and travellers in the sparsely populated country without fingers and toes. Sometimes arms and legs would need to be amputated. Quite a few would be labelled with their impairment, going by names, such as Kristján fótalausi or Kristján the legless (Vilhjálmsson 1941). Fótalausi seems to have been a popular byname or tag for people whose legs had been amputated. Guðrún Bjarnadóttir (1770-1859), known as Gunna fótalausa, suffered frostbite at the age of 15 and both her feet were amputated at the level of the ankle. As a poverty-stricken orphan she rose to become a prosperous farmer, landowner, and boat-builder (Jónsson 1914, p. 181-182). Another was Ásmundur Ásmundsson (1845-1924), a.k.a. Ásmundur fótalausi, who due to frostbite lost also both legs at the ankle, as well as his left arm by mid forearm when he was in his mid-20's. He later emigrated to Canada to become, for a while, a quite prosperous farmer (Porbergsson 1917, Anon 1924). Jón S. Sigurðsson (1856-1931), or Jón fótalausi, lost both 
legs just below the knee after being shipwrecked in 1880 but continued as a fisherman for decades after. A fellow fisherman claimed that "few were his equals when it came to drive and hardiness at sea" (Víglundsson, 1969, p. 62). The same person also describes his work method:

To my knowledge he preferred rowing vessels. In these there was a rib (röng) mid-ship. In front of the rib placed a bar right across the width of the boat which he would push his knees against when rowing. He would crawl on four feet from prow to stern and was quick about it (Víglundsson 1969, p. 61-62).

Several other examples of people that carried the same labelling of fótalausi due to their impairment can be found through-out the 19th century. The testimonies sometimes bear witness to curious resilience and resourcefulness in a society that offered no public support or readymade support equipment.

The case of Kristján Benediktsson (1803-1891), who went by the name Kristján fótalausi, is compelling. His story was recorded by poet and scholar Konráð Vilhjámsson, published in 1941. Vilhjámsson-based his account on the testimonies of people who knew Kristján from mid-century onwards. Kristján suffered severe frostbite in 1826 after getting lost in a snowstorm. The result was that both legs were amputated beneath the knee (with a farm saw usually used for cutting timber), as well as his fingers above the knuckles closest to the hand (proximal phalange) - with a chisel, leaving only small stubs. Frostbite had also scathed his nose which was partly removed "so you could from then look directly into his nostrils" (Vilhjálmsson 1941, p. 26). Surviving this, he lived well into his 80 s, residing as pauper at different households in upper Bárðardalur in the district of Ljósavatn in Iceland's north.

Kristján is described as a robust child, but unruly and mischievous, later medical knowledge might have diagnosed him as having a disorder of some sort. This personal trait seems to have followed him through adulthood. At least he seems not always to have been a welcome addition to the households to which he was assigned as pauper, having resided at a number of farmsteads through the years. Conversely, in spite of being described as fierce looking and commanding a ferocious voice, he was said to have been particularly good with children.

From the time of his impairment, Kristján was unable to walk but crawled wherever he went with knees and stubs wrapped in calfskin for protection. Apart from attending to children, he is said to have had various chores which were beneficiary for the household. His job was for instance to card horsehair and making ropes, his finger-stubs reportedly sensitive enough to pick up a needle from the floor. Another job was to administer hand operated grinding mills. He also worked outside, is claimed to have been a specialist in handling "great big rocks that he would roll for a distance and lift to his chest and pile up, as he was extremely strong and hardy, all things considered" (p. 27). 
Due to what is described as his "impetuosity" some households seem to have found it necessary to exclude him at times form the communal baðstofa, "in some places he was kept on a stall in the cowhouse, particularly during winter" (p. 29). This segregation is explained with reference to his mental state while it simultaneously suggests that this was an emergency measure. Thus, in terms of activity he seems to have had valued roles within the household as he would fulfil work tasks that were beneficiary for the sustenance of the farm, while his participation in the everyday life of the farmstead seems to have been restricted at times, but not always as positive reference to his engagement with children bears witness. In light of his contribution to the household, it would have been seen as both normal and desirable for him to share the common space of the farmhouse and thus participate in the economic and cultural activities of that took place in the collective space of the baðstofa.

\section{The case of Árni Jakobsson of Víðasel}

Population growth in the early 19th century led to increased settlement in the highlands of Iceland's north-east, a vast area that had only sporadically been populated through the centuries. The heyday of this settlement was between 1820-1860 and some farms survived into the 20th century. While these farmsteads consisted of extensive grasslands suitable for sheep grazing, they proved extremely meagre in terms of revenue due to the harsh climate conditions in the highlands, with significantly shorter summers and severe winters.

The following discussion draws on the published memoirs of Árni Jakobsson (1963), born 1891 in the district of Mývatn. In the spring of 1915 Árni Jakobsson and his wife Sigríður Kristín Sigurgeirsdóttir acquired the cottage of Víðasel in the highlands west of lake Mývatn. They had gotten married the previous summer with the intention of becoming farmers. Their luck turned for the worse in late 1914 when Árni contracted polio that left him paralysed from the waist down. This did, however, not dissuade the couple form acting on their dreams, seeking independence and establishing their own household. In many ways the housing predicaments that Árni describes in the following are of the kind that were common in the 19th century. In the period that he describes from 1914-1926 the social structure that fostered this type of habitation is, however, about to cave in, giving way to new building materials and urbanised modernity.

Árni's memoirs offer a detailed description of the state and layout of the cottage. He describes the different spaces of the bær and especially the main living quarters, the baðstofa. As such his recollections testify to how his impaired body was met by the cottage architecture. Arriving with their belongings at Víðasel in 1915 the couple found the buildings in dismal condition and need of repair. Árni recalls his initial impression after the trying journey, seeing the farmhouse for the first time, he writes, "I am filled with 
dread" (p. 74). As he was physically quite weak during their first summer at Viðasel the rebuilding of the baðstofa was mostly left to his father, who accompanied the couple, and to Sigríður. While the rebuilding took place, Árni spent most of his time in a small shed intended as shelter for sheep adjacent to the cottage. His description gives an idea of his physical state:

I'm mostly alone in the shed while the rebuilding takes place. Nothing much to do and the solitude is dreary. When the weather is good, I try to crawl outside. Here, there are no high thresholds or other obstacles and I have become strong enough to crawl a bit without assistance. If I am helped up, I can even stand for a moment by holding myself upright with my hands (p. 78).

To his dismay, Árni's physical state makes it impossible for him to oversee or take part in the renovations as was his intention and would have been expected of him as the farmer of Víðasel, had he not been hindered by impairment. Though obviously anguished by his predicaments he notes on the positive side the lack of hurdles in the shed which makes it easier (than if he resided in the farm) to move around and go outside. Here, it can thus be said that the lack of architecture reduced his immobility.

A couple of years later in the summer of 1917, renovations are again underway with the rebuilding of the open hearth kitchen, pantry, and cowshed. He has now gained strength in his hands and participates fully in the project.

My father built the walls of these buildings mostly on his own. The foundations were of stone and the rest of the walls turf. I cut most of the turf-blocks [for the wall], as well as the turf for the roof. I had gained so much strength in my hands that I could accomplish this task, but I had to either kneel down or sit flat on the ground, so my posture was rather demanding (p. 103).

Here, Árni has gained his position as farmer. He is an active participant in renovating/rebuilding his own farm. In the context of the Icelandic peasant society his determination is an indication of his activity and participation. This is what accomplished farmers did if they intended to pursue a living on the farm. To paraphrase Imrie (2004), challenging the impediments placed in his way, the resourceful farmer set about reproducing appropriate useable spaces at the farm.

The accompanying photograph (see Fig. 8.1) from the early 1910s shows previous residents in front of the entrance of the highland cottage. From this photograph, Árni's detailed description of the interior from his memoirs (Jakobsson 1963, p. 74-79) and aerial photographs of the ruins (Ingason 2020) an outline can be drawn up of the living area (baðstofa) and sheep house outlining the layout of the building seen on the photograph. In minute 


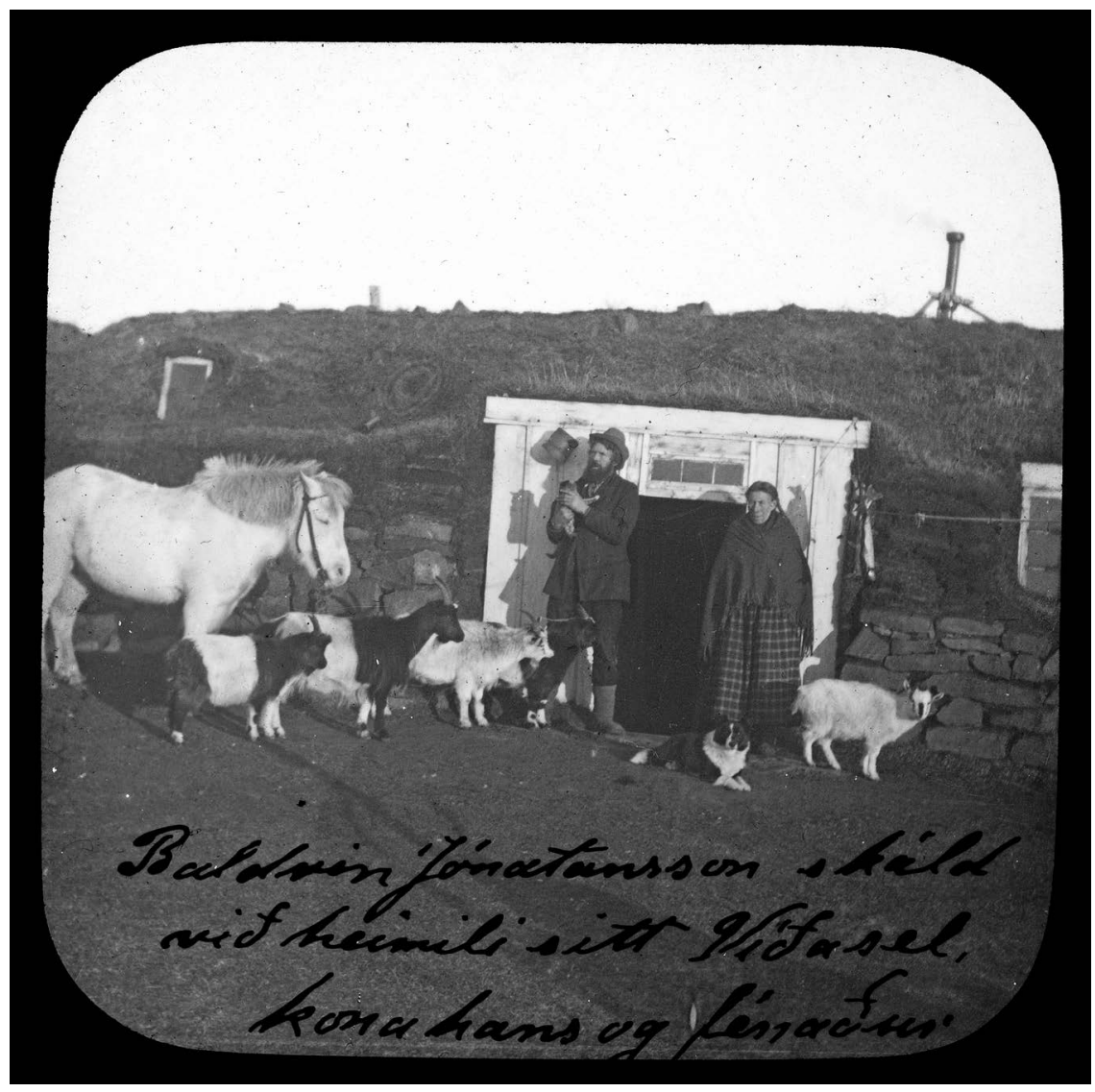

Figure 8.1 Víðasel cottage.

detail Árni describes the entrance in the middle of the northern side, with timber panel on either side and a tree pane window above the door. When inside a corridor divided the building, about two meters wide. The sheep house was on the left (northern side) and the baðstofa to the right. You entered the baðstofa through a door while the sheep house, holding around 20 sheep, was separated from the corridor with railings. Beyond the corridor, east of this main building, were the kitchen, pantry (both rebuilt in 1917 as described above), barn and the shed where Árni spent his days during the initial renovation (Jakobsson 1963, p. 74-76).

The baðstofa was according to Árni "five [Danish] ells on each side," which means that the living area of the cottage was in total no more than ten square meters (Jakobsson 1963, p. 75). In this confined space the inhabitants would spend sometimes days on end, especially during winter, in the company of each other. According to the national census of 1920 
(NAIS 1920) in addition to Árni and Sigríður, his parents were living in the cottage, as well as two domestic servants, a boy of 15 years and a 43-yearold female. Within the baðstofa was a stove, bedsteads, and a small table. Árni describes the furniture in the living area as consisting of primitive bedsteads along the southern wall made of mud, brushwood and canvas and separated by a gable. A stove was in the north-east corner and "a semi-circular table attached to the wall under the window ... where two could eat at once if the food was served in the traditional way where edibles were served on a single plate and spoon food in bowls." One window "with six small panes" was on the baðstofa, above the table and facing west (Jakobsson, 1963, p. 75). The edge of the window can be seen on the lefthand side of the photograph.

As noted above the baðstofa was the space the residents would spend most of indoor life, which meant a substantial part of their time, at least during the long winter months from October till April. The fact that so much of the activities of the household took place within this confined space can thus be seen to have facilitated Árni's inclusion and social participation as head of household. Rather than seeing Árni as a victim to substandard housing, the primitive accommodation can be interpreted as opening up possibilities of activity and participation for a person with reduced mobility.

Like in other pre-industrial societies the question of moving from one place to another, such as between home and workplace, was less an issue than it would be in the industrialised urban spaces. In Víðasel the cottage industry was updated in 1919 when Árni bought a knitting machine with financial assistance from friends and neighbours.

The knitting machine served me well, I soon got all sorts of orders from persons in the districts of Reykjadalur and Mývatn. After I came into the possession of the machine, I sometimes had some money to spend, and it proved convenient for paying off debts. People from Mývatn sometimes paid with eggs and trout which was a windfall for us. And last but not least my circumstances took a turn for the better when I got the machine, as the boredom of idleness no longer haunted me (Jakobsson 1963, p. 108).

Árni's impairment did not hinder him from contributing to the economic sustainability of the household, taking part in the cottage industry. $\mathrm{He}$ seems, however, to have only undertaken chores that would have been considered manly. He cuts turf and operates the knitting machine, which is comparable with ministering the loom, which traditionally was a man's job within the cottage industry. Even plagued by boredom he does not venture into the female work domain, even though his wife would overtake some of the outdoor work that was traditionally the male-partner's role. Árni and Sigríður were the last occupants of Víðasel and left the cottage in the 
autumn of 1926 to settle in the emerging town of Húsavík. They were of the last generation that lived in a turf-house.

\section{Conclusion}

The spatial nature of the 19th century turf-house, where the whole household would "live practically all their indoor life in the baðstofa" (Karlsson 2000 , p. 250), raises important considerations about disability and participation. Harsh and unstable climate conditions and available building resources dictated the design, creating these condense multi-purpose places of gathering and interaction. As with standardised modernist architecture, the vernacular design of the turf-houses shaped the material context of the social space. For social inclusion access to these social spaces of the cottages was imperative. And access, as disability scholar Tanya Titchkosky (2011, p. 4) argues, "is tied to the social organization of participation, even to belonging."

The social structure, though in many ways notoriously inhumane when it came to the dispossessed, can also be seen to have influenced social inclusion actualised in the baðstofa. This adheres to both adult paupers and vagrants who in many cases were persons with impairment of some sort. As a form of social security, and ensuring farmers cheap labour, paupers were assigned to farms and as a rule shared the space of the baðstofa with other members of the households. When vagrants turned up at farmsteads, they also were generally put up in the same communal space as anyone else (Jónsson 2018) and in that way social legislation of the peasant society contributed to this type of spatial inclusion.

Though the case of Kristján "the legless" Benediktsson shows that not everyone was always welcomed in the baðstofa, it was more often than not an inclusive social space. The household being the economic unit, people with impairments were required to contribute with their labour in a way that was beneficiary for the sustainability of the farm. If not too unruly from the perspective of the master of the house, it would have been seen as beneficial for the household to include Kristján in the activities in the baðstofa, where an eye could be kept on him to ensure his diligence when it came to completing his chores. By sharing the social space days on end the inclusion also extended to cultural activities and consumption; storytelling, gossiping, frolicking, chanting of rímur, recitals from secular and religious texts, receiving visitors and so forth. In this regard access to the social space involved inclusion and participation.

Árni Jakobsson's descriptions of the interior at Víðasel-cottage gives an example of how the condense space of the baðstofa and other buildings in an underprivileged peasant household framed the disability of the physically impaired farmer. It did so in a quite different way than it did later on when Árni and his wife abandoned the farmstead and moved to the village of Húsavík, where Árni ended up commuting in a "deluxe model" of 
a hand propelled motor carriage. At Viðasel on the other hand, Árni had no support equipment to aid his mobility, save for some ropes he used for pulling himself up to a raised position (Jakobsson 1963). However, because of the architectural structure of the cottage, the baðstofa being the social space for working, eating, sleeping, engaging in cultural activities, etc., he was quite active in terms of participation. Brown et al. (2004, p. 463) define participation as referring to "engagement in activities that are intrinsically social, that are part of household or other occupational role functioning, or that are recreational activities occurring in community settings." From this perspective it seems reasonable to conclude that as regards the turf-house, in comparison with standardised modernised design, the former had fewer disabling effects on the person with physical impairment than the latter. Vernacular architecture of the past, because of the nature of its structure and its plasticity and lack of standardisation, can thus be seen, to an extent, as more in tune with the differing demands of diverse human bodies.

\section{References}

Anon., 1924. Æfiminning Ásmundar Ásmundssonar 1845-1924. Heimskringla, 17, 2-3.

Brown, M., Dijkers, M., Gordon, W. A., Ashman, T., Charatz, H., Cheng, Z., 2004. Participation objective, participation subjective: A measure of participation combining outsider and insider perspectives. Journal of Head Trauma Rehabilitation, 19 (6), 459-481.

Chang, F. H., and Coster, W. J., 2014. Conceptualizing the construct of participation in adults with disabilities. Archives of Physical Medicine and Rehabilitation, 95 (9), 1791-1798. Doi: 10.1016/j.apmr.2014.05.008

CRPD., 2006. United Nations Convention on the Rights of Persons with Disabilities. New York: United Nations.

Emilsson, T., 1976. Fátakt fólk: Aviminningar. Reykjavik: Mál og menning.

Finkelstein, V., 1981. Disability and the helper/helped relationship: An historical view. In: A. Brechin et al., eds. Handicap in a Social World. Sevenoaks, UK: Hodder \& Stoughton in association with the Open University Press, 65-78.

Gíslason, M., 1977. Kvällsvaka: En isländsk kulturtradition belyst genom studier $i$ bondebefolkningens vardagsliv och miljö under senare hälften av 1800-talet och början av 1900-talet. Uppsala: University of Uppsala.

Gleeson B., 1999. Geographies of Disability. Routledge: London and New York.

Gleeson B., 2001. Domestic space and disability in nineteenth-century Melbourne, Australia. Journal of Historical Geography, 27 (2), 223-240. Doi: 10.1006/ jhge. 2000.0300

Guðjónsson, S., 2013a. Aðbúnaður geðveikra á Íslandi og umbatur yfirvalda fyrir daga geðspitala. Thesis (PhD). University of Iceland.

Guðjónsson, S., 2013b. Í “öruggri” vist eða förufólk? Hlutskipti fólks með geðsjúkdóma á Íslandi á 19. öld. In: H. B. Sigurjónsdóttir, Á. Jakobsson and K. Björnsdóttir, eds. Fötlun og menning: Íslandssagan i öðru ljósi. Reykjavik: Félagsvísindastofnun Háskóla Íslands og Rannsóknarsetur í fötlunarfræðum, 127-144. 
Gunnlaugsson, G. Á., 1983. Löggjöf um fátækraframfærslu á Íslandi á 18. öld. Saga, 21, 39-72.

Gunnlaugsson, G. Á., 1988. Family and household in Iceland 1801-1930. Studies in the relationship between demographic and socio-economic development, social legislation and family and household structure. Uppsala, SE: Acta Universitatis Upsaliensis.

Gunnarsson, G., 1987. Upp er boðið Ísaland. Einokunarverslun og islenskt samfélag 1602-1787. Reykjavik: Örn og Örlygur.

Guttormsson, L., 2008. Fræðsluhefðin: Kirkjuleg heimafræðasla. In: L. Guttormsson, ed. Almenningsfræðsla á Íslandi 1880-2007. Reykjavik: University of Iceland Press, 21-25.

Hafsteinsson, S.B., 2010. Museum politics and turf-house heritage. In: G.P. Jóhannesson and H. Björnsdóttir, eds. Rannsóknir í félagsvísindum XI. Reykjavik: Félagsvísindastofnun Háskóla Íslands, 266-273

Hafsteinsson, S. B., 2019. "Icelandic putridity": Colonial thought and Icelandic architectural heritage. Scandinavian Studies, 91 (1-2), 53-73.

Hafsteinsson, S. B., and Jóhannesdóttir, M. G., 2015. Moldargreni og menningararfur: Útrýming og arfleifð torfhúsa. In: Ó. Rastrick and V.Tr. Hafstein, eds. Menningararfur á Íslandi: Gagnrýni og greining. Reykjavík: University of Iceland Press, 193-218.

Hálfdanarson, G., 2008. Private spaces and private lives: Privacy, intimacy, and culture in Icelandic 19th-century rural homes. In: P. François, T. Syrjämaa and H. Terho eds. Power and culture: New perspectives on spatiality in European history. Pisa, IT: Edizioni Plus, 109-124.

Halldórsdóttir, E. D., 2020. Óhreinu börnin hennar Evu: Holdsveiki á Íslandi og $i$ Noregi. Reykjavik: Ugla.

Imrie, R., 2000. Disability and discourses of mobility and movement. Environment and Planning A: Economy and Space, 32 (9), 1641-1656.

Imrie, R., and Edwards, C., 2007. The geographies of disability: Reflections on the development of a sub-discipline. Geography Compass, 1 (3), 623-640. Doi: 10.1111/j.1749-8198.2007.00032.x

Imrie, R., 2004. Disability, embodiment and the meaning of the home. Housing Studies, 19 (5), 745-763. Doi: 10.1080/0267303042000249189

Ingason, U., 2020. Aerial photographs of Víðasel. At: Pingeyjarsýsla: Archealogical society of Pingeyjarsýsla.

Jakobsson, Á., 1963. Á völtum fótum: Avisaga. In: P. Friðgeirsson ed. Akureyri, IS: Bókaforlag Odds Björnssonar.

Jónasson, J., 2010. Íslenskir pjóðhattir. In: E. Ó. Sveinsson, ed. Reykjavik: Opna.

Jónsson, F., 1914. Ólafur á Kjörseyri og ætt hans. Eimreiðin 3, 176-183.

Jónsson, G., and Magnússon M. S., eds., 1997. Hagskinna. Icelandic historical statistics. Reykjavik: Statistics Iceland

Jónsson, J., 2018. Á mörkum mennskunnar: Viðhorf til förufólks i sögnum og samfélagi. Reykjavik: University of Iceland Press.

Karlsson, G., 2000. Iceland's 1100 years: The history of a marginal society. London: C. Hurst.

Kreps, T., 2019. Sustainability in Cold Climates: A Vernacular Study of Icelandic Turf Houses. Thesis (MA). Laurentian University.

Lárusson, H., 2014. Íslenski bærinn. Tímarit Máls og menningar, 75 (1), 17-35.

Le Goff, J., 1988. Medieval civilization 400-1500. Trans, J. Barrow. Oxford: Blackwell, 1988. 
Macdonald, S. J., et al., 2018. 'The invisible enemy': Disability, loneliness and isolation. Disability \& Society, 33 (7), 1138-1159. Doi: 10.1080/09687599.2018. 1476224

Magnússon, M.S., 1985. Iceland in transition: Labour and socio-economic change before 1940. Lund, SE: Ekonomisk-historiska Föreningen.

Magnússon, S.G., 2019. Hús og híbýli albýðumanna. Fátækt á Íslandi á síðari hluta 19. aldar og fram á pá 20. í máli og myndum. In: F. Jónsson, S. Ólafsdóttir and S.G. Magnússon. Híbýli fátaktar. Húsnæði og veraldleg gaði fátaks fólks á 19. öld og fram á 20. öld. Reykjavik: University of Iceland Press, 15-51.

Metzler, I., 2013. A social history of disability in the Middle Ages Cultural Considerations Of Physical Impairment. Abington, PA: Routledge.

NAIS, 1920. National Archives of Iceland (NAIS) Census Database. Reykjavík: National Archives of Iceland.

Oliver, M., 1990. The Cultural Production of Impairment and Disability. In: M. Oliver, ed. The politics of disablement. critical texts in social work and the welfare state. Palgrave: London, 12-24.

Oliver, M., and Barnes, C., 2012. The new politics of disablement. Basingstoke, UK: Palgrave Macmillan.

Rastrick, Ó., 2012. Postulínshundar og glötuð meistaraverk: Um verkefni íslenskrar menningarsagnfræði á priðja áratug tuttugustu aldar, Ritið, 12 (1), 31-47.

Rastrick, Ó., 2013. Háborgin: Menning, fagurfraði og pólitík í upphafi tuttugustu aldar. Reykjavik: University of Iceland Press.

Shakespeare, T., 2018. Disability: The basics. Abingdon, PA: Routledge.

Sigurðardóttir, S., 2008. Building with turf [online]. Glaumbær, IS, Skagafjörður Historical Museum. Available from: http://hdl.handle.net/10802/6870 [Accessed 1 March 2021].

Sigurðardóttir, S., 2012. Traditional Building Methods [online]. Glaumbær, IS, Skagafjörður Historical Museum. Available from: Glaumbær. http://hdl.handle. net/10802/9062 [Accessed 1 March 2021].

Sigurðardóttir, S., 2020. Viðhorf til nytja- og minjagildis torfbygginga. Rannsóknir um minjaarf I-torfbyggingar. Rannsóknaskýrslur Ferðamáladeildar Háskólans á Hólum [online]. Sauðárkrókur, IS, Háskólinn á Hólum. Available from: https:// www.holar.is/static/files/Rannsoknir/Ferdamaladeild/Utgefidefni/vidhorf_til_ nytja-_og_minjagildis_torfbygginga_loka.pdf [Accessed 1 March 2021].

Snævarr, Á., 2019. Maðurinn sem elskaði Ísland: Paul Gaimard og Íslandsferðir hans 1835-1836. Reykjavik: Mál og menning.

Stefánsson, H., 2013. Af jörðu: Íslensk torfhús. Reykjavik: Crymogea.

Titchkosky, T., 2011. The question of access: Disability, space, meaning. Toronto: University of Toronto Press.

Porbergsson, J., 1917. Ásmundarsaga fótalausa. Eimreiðin, 3, 173-177.

van Hoof, J., and van Dijken, F., 2008. The historical turf farms of Iceland: Architecture, building technology and the indoor environment. Building and Environment, 43 (6), 1023-1030. Doi: 10.1016/j.buildenv.2007.03.004

Víglundsson, P. P., 1969. Hetjan fótalausa og eiginkonan. Blik: Ársrit Vestmannaeyja, $27,40-62$.

Vilhelmsson, V., 2017. Sjálfstatt fólk: Vistarband og islenskt samfélag á 19. öld. Reykjavik: Sögufélag.

Vilhjálmsson, K., 1941. Frá Kristjáni fótalausa. Gríma, 16, 24-29. 
Warrington, M., 2001. 'I must get out': The geographies of domestic violence. Transactions of the Institute of British Geographers, 26, 365-382. Doi: 10.1111/14755661.00028

Wiesel, I., and van Holstein, E., 2020. Disability and place. In: Edensor, T., Kalandides, A. and Kothari, U. eds. The routledge handbook on place. London and New York: Routledge, 304-312. 